\title{
Dragonflies and damselflies (Insecta: Odonata) from a Cerrado area at Triângulo Mineiro, Minas Gerais, Brazil
}

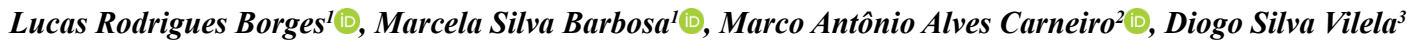 \\ \& Jean Carlos Santos ${ }^{1 *}$ [C \\ ${ }^{1}$ Universidade Federal de Uberlândia, Instituto de Biologia, Av. Pará 1720, 38405-320. Uberlândia, MG, Brasil \\ ${ }^{2}$ Universidade Federal de Ouro Preto, Instituto de Ciências Exatas e Biológicas, Campus Morro do Cruzeiro, \\ 35400-000. Ouro Preto, MG, Brasil \\ ${ }^{3}$ Universidade de São Paulo, Faculdade de Filosofia, Ciências e Letras de Ribeirão Preto, 14040-901. \\ Ribeirão Preto, SP, Brasil \\ *Corresponding author: Jean Carlos Santos, e-mail: jcsantosbio@gmail.com
}

BORGES, L.R., BARBOSA, M.S., CARNEIRO, M.A.A., VILELA, D.S., SANTOS, J.C. Dragonflies and damselflies (Insecta: Odonata) from a Cerrado area at Triângulo Mineiro, Minas Gerais, Brazil. Biota Neotropica. 19(1): e20180609. http://dx.doi.org/10.1590/1676-0611-BN-2018-0609

\begin{abstract}
Odonata is considered, among the aquatic insect orders, the second largest group in number of species. Its global richness is estimated in about 6,000 described species. The Brazilian richness represents around $14 \%$ of the world's odonatofauna, however, the knowledge on Brazilian dragonflies distribution is still poor. This study purpose an inventory of the dragonflies species present in aquatic habitats from a Preserved Area according to the Brazilian Forest Code, located in the Cerrado biome at Triângulo Mineiro, Minas Gerais. In the dry season, from April to June of 2017, we collected 680 specimens belonging to 36 species and six families. Among the collected species, Elasmothemis williamsoni was observed by the first time in Minas Gerais State, and we also found a new species of Tigriagrion (Zygoptera: Coenagrionidae) which is being described by taxonomists. Considering the fast agricultural advance over natural Cerrado systems, species lists can be important to define priority conservation areas for odonate species.
\end{abstract}

Keywords: inventory, biodiversity, vereda, Odonata.

\section{Libélulas e donzelinhas (Insecta: Odonata) de uma área de Cerrado no Triângulo Mineiro, Minas Gerais, Brasil}

Resumo: Odonata é considerada a segunda ordem de insetos com maior número de espécies de insetos aquáticos. Sua riqueza global é estimada em cerca de 6.000 espécies descritas. A odonatofauna encontrada no Brasil representa cerca de $14 \%$ da riqueza mundial, no entanto, o conhecimento sobre a distribuição de libélulas brasileiras ainda é incipiente. Este estudo teve como objetivo um inventário das espécies de libélulas presentes em habitats aquáticos de uma Área Preservada de acordo com o Código Florestal Brasileiro, localizada no bioma Cerrado do Triângulo Mineiro, em Minas Gerais. Na estação seca, de abril a junho de 2017, foram coletados 680 espécimes pertencentes a 36 espécies e seis famílias. Entre as espécies coletadas, Elasmothemis williamsoni foi observada pela primeira vez no Estado de Minas Gerais, e foi encontrada também uma nova espécie de gênero Tigriagrion (Zygoptera: Coenagrionidae) que está sendo descrita. Considerando o rápido avanço da agricultura sobre os sistemas naturais do Cerrado, as listas de espécies podem ser importantes para definir áreas prioritárias para a conservação de espécies de Odonata.

Palavras-chave: inventário, biodiversidade, vereda, Odonata. 


\section{Introduction}

Among the aquatic insects, Odonata (dragonflies and damselflies) is considered the second largest group in number of species (Djikstra et al 2014). Although the actual number of described species can be close to 7,000 (Kalfman et al. 2008), more recent data shows this number only near 6,000 (Djikstra et al. 2014). In the tropical regions, e.g., Neotropical region (von Ellenrieder 2009a) Odonata shows high diversity, being Brazil the country with the most known species richness: 856 species, which represents around $14 \%$ of the global fauna (Pinto 2018).

Studies involving Odonata are raising in Brazil (see Miguel et al. 2017), since odonates are charismatic insects (Corbet 1999), has a well resolved taxonomic status (Garrison et al. 2006, 2010, Lencioni 2005, 2006, 2017) and are easily observed and manipulated in the field (De Marco \& Vianna 2005). Many of these studies are focused on describing new species (e.g., Guillermo-Ferreira et al. 2016, Ávila et al. 2017, Vilela et al. 2018), in species inventories (e.g. Vilela et al. 2016), and also in ecological studies (Klein et al. 2018), at different localities in Brazilian biomes, from the Pampas in the southern (e.g. Renner et al. 2017) to the Amazonic rain forest, in the northern Brazil (e.g. MonteiroJúnior et al. 2014). Overall, these studies are adding more information about the distribution of species in different Brazilian states (Machado 1998, Costa et al. 2000, Costa \& Oldrini 2005), and helping to reveal the Odonata Brazilian diversity throughout its biomes. However, even though Odonata is actually one of the most studied insect orders in Brazil, there still is a lack of knowledge about its distribution in many places in the national territory.

One reason to this bias is that many studies that aim to inventory biodiversity are concentrated near locations that offer convenient access, infrastructure, and logistics (Dennis \& Thomas 2000, Hortal et al. 2007), and have historical patterns of colonization and inventorying (Bini et al. 2006, Meyer et al. 2015). In Brazil, there is an enormous gap of information about the northeast region, where only some sporadic captures were made (De Marco \& Vianna 2005). In Minas Gerais state, most of studies are concentrated in the central and south regions (Souza et al. 2013, Almeida et al. 2013, Bedê et al. 2015). Little is known about the odonatofauna from Triângulo Mineiro, a region located on the Cerrado domain, in the western of the state (e.g., Vilela et al. 2016). The fact that the Triângulo Mineiro is largely occupied by agrosystems increases the priority for Odonata inventories on this area (Silva 2000, De Marco \& Vianna 2005).

For instance, the Cerrado biome is a biodiversity hotspot located at the central region of Brazil (Myers et al. 2000). In the past years, many studies were made in relation to the accelerated process of deforestation of the Brazilian Cerrado (Ferreira-Peruquetti \& Fonseca-Gessner 2003, Carvalho et al. 2013, Dutra \& De Marco Jr. 2015) and those studies shows that Odonata community can be affected by the current environmental disturbances. Furthermore, the lack of knowledge about biodiversity data can strongly influence species distribution models, widely used for analytical and predictive tools in conservation (Peterson et al. 2011). Then, considering the current advance of agrosystems on Cerrado native vegetation and the gaps of knowledge on the distribution of Brazilian dragonfly species, information about species distribution may contribute to the elaboration of effective strategical plans for the conservation (Whittaker et al. 2005, Diniz et al 2010) of the odonates fauna. Therefore, this study aims to provide a checklist of odonate species from a Cerrado area at Triângulo Mineiro, Minas Gerais, where the principal activity is the eucalyptus forests. Additionally, this study aims to contribute with information about the distribution of Odonata at Brazilian Cerrado.

\section{Material and methods}

\section{Study area}

The study was made at an eucalyptus farm named Fazenda Nova Monte Carmelo belonging to the company Duratex ${ }^{\odot}$, located in five municipalities (Araguari, Estrela do Sul, Indianópolis, Nova Ponte, and Romaria) of Triângulo Mineiro region, Minas Gerais state, Brazil (18 $\left.57^{\prime} \mathrm{S}, 47^{\circ} 43 \mathrm{~W}\right)$. The silviculture activities of Duratex started about 20 years ago, with the introduction of Pinus sp. in the area. After some years, the Pinus sp. plantation started to be replaced by Eucalyptus sp. and today, almost all the farming area are occupied by eucalyptus silviculture (Duratex S.A. Personal Communication). The Fazenda Monte Carmelo area (52,000 ha) is mainly covered by the eucalyptus farming (38,000 ha) and had left about 13,000 ha of natural Cerrado areas, according to the Brazilian Law $n^{\circ} 12.651$, the Forest Code, that demands the conservation of $20 \%$ of particular rural properties natural areas, located at Cerrado biome, as a Legal Reserve and the conservation of water bodies, if there is some in the property (Brasil 2012). All the sampling areas were fragments located within the Preserved Area of Nova Monte Carmelo (PANMC) (Figure 1) that is surrounded by a matrix of eucalyptus plantations, and some other farming activities in the neighboring farms, as wheat and corn cultures. The PANMC is covered by Cerrado biotopes, as stricto sensu cerrado, campos de murundus and veredas (which are composed by permanently saturated soil, forming small to large ponds). The climate in the region is classified as Aw in the Köppen system, with two distinct seasons: a rainy (October-March) and a dry season (April-September) with annual mean temperature between $20^{\circ} \mathrm{C}$ and $22^{\circ} \mathrm{C}$ and rainfall of $1,450 \mathrm{~mm}$ (Gottsberger \& SilberbauerGottsberger 2006, Alvarez et al. 2013).

Altogether, 13 aquatic environments were sampled (Figure 1), that could be natural vereda swamps (VE) or artificial lakes (AL) originated by modifications of the land, made to introduce the eucalyptus farm, and by opening roads. Most of the sampled points were exclusively lentic habitats, however, in three points (S3, S5, S13), we found tight channels with moving water nearby to the lentic habitats. Some of the aquatic environments had a riparian zone composed by native cerrado mature shrubs and trees, and those were classified as shaded areas ( $\mathrm{SH})$ whereas others were located in open areas (OP), with fields predominantly covered by grasses, with only few sparse shrubs (Soares et al. 2015). The area of each lake was measured by using Google Earth Pro. The area, coordinate, habitat characteristic (VE or AL), and riparian zone vegetation tipe (SH or OP) of each lake are listed on Table 1.

\section{Data collection}

We sampled adult dragonflies from April 2018 to July 2018. The sampling were made during the peak time of Odonata activities, between 10:00h and 15:00h, with the aid of entomological nets used by the two members of the team (Renner et al. 2015). Each site was sampled during three hours, by walking around marginal zones of lakes or flooded 


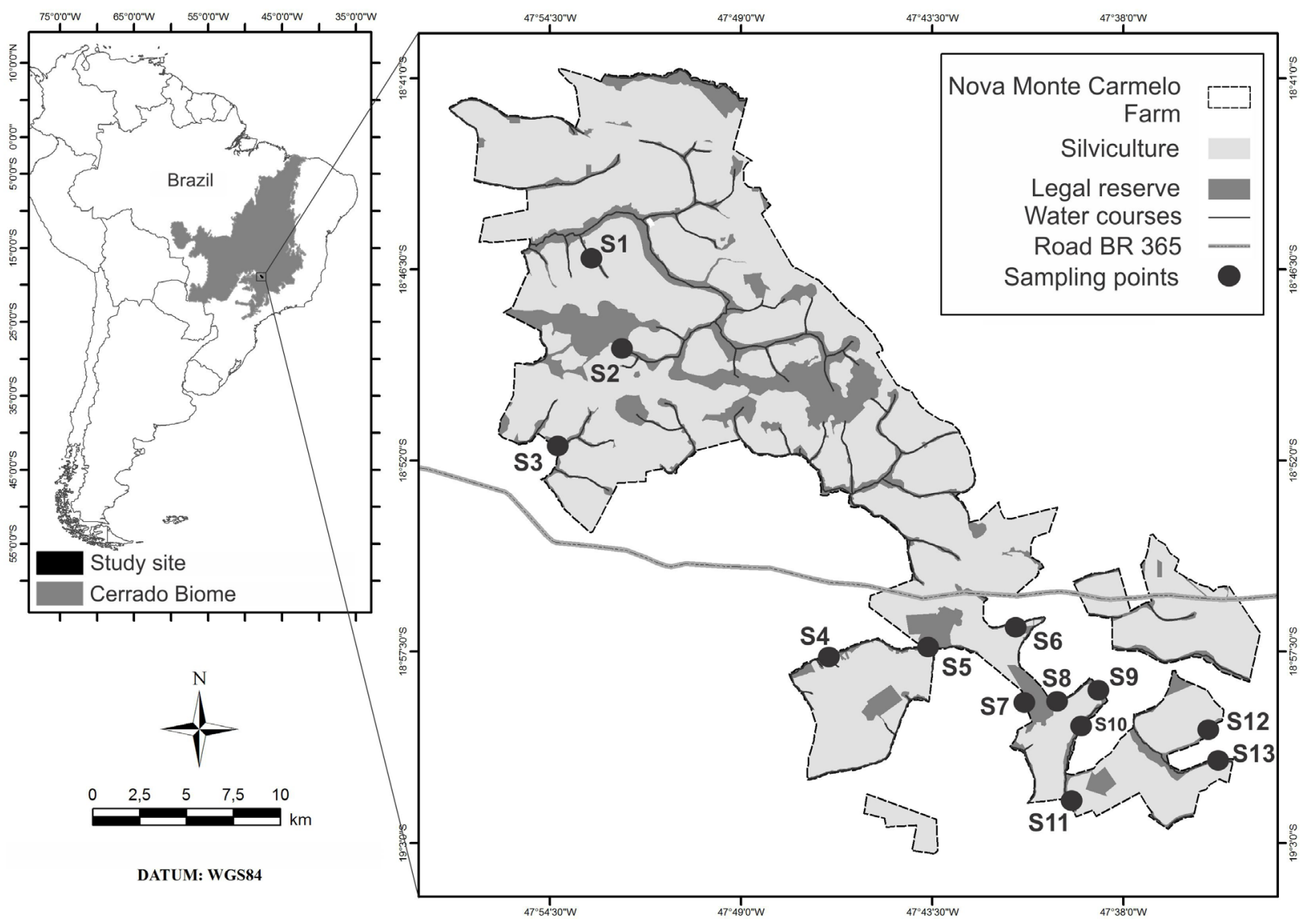

Figure 1. Map of Fazenda Nova Monte Carmelo (MG), Brazil, showing the sampling points, the eucalyptus plantation area, the Legal Reserve, watercourse, and the BR 365 highway.

Table 1. Lakes characteristics. The coordinates and the area of each lake were acquired by using Google Earth Pro. AL: Artificial lake; VE: Vereda; OP: Open area; SH: Shaded area.

\begin{tabular}{lcccc}
\hline Lakes & Aquatic Habitat & Vegetation Tipe & Coordinates & Area \\
\hline S1 & AL & SH & $18^{\circ} 46^{\prime} 14^{\prime \prime} \mathrm{S}, 47^{\circ} 53^{\prime} 12^{\prime \prime} \mathrm{W}$ & $4028,7 \mathrm{~m}^{2}$ \\
S2 & VE & OP & $18^{\circ} 48^{\prime} 35^{\prime \prime} \mathrm{S}, 47^{\circ} 52^{\prime} 17^{\prime \prime} \mathrm{W}$ & $5077,8 \mathrm{~m}^{2}$ \\
S3 & VE & SH & $18^{\circ} 51^{\prime} 42^{\prime \prime} \mathrm{S}, 47^{\circ} 54^{\prime} 12^{\prime \prime} \mathrm{W}$ & $5077,4 \mathrm{~m}^{2}$ \\
S4 & OP & $18^{\circ} 57^{\prime} 39^{\prime \prime} \mathrm{S}, 47^{\circ} 46^{\prime} 24^{\prime \prime} \mathrm{W}$ & $246,1 \mathrm{~m}^{2}$ \\
S5 & SH & $18^{\circ} 57^{\prime} 19^{\prime \prime} \mathrm{S}, 47^{\circ} 43^{\prime} 36^{\prime \prime} \mathrm{W}$ & $19124,9 \mathrm{~m}^{2}$ \\
S6 & VE & SH & $18^{\circ} 56^{\prime} 42^{\prime \prime} \mathrm{S}, 47^{\circ} 41^{\prime} 07^{\prime \prime} \mathrm{W}$ & $1800,0 \mathrm{~m}^{2}$ \\
S7 & VE & OP & $18^{\circ} 58^{\prime} 51^{\prime \prime} \mathrm{S}, 47^{\circ} 40^{\prime} 47^{\prime \prime} \mathrm{W}$ & $1309,3 \mathrm{~m}^{2}$ \\
S8 & AL & OP & $18^{\circ} 58^{\prime} 56^{\prime \prime} \mathrm{S}, 47^{\circ} 39^{\prime} 47^{\prime \prime} \mathrm{W}$ & $1287,7 \mathrm{~m}^{2}$ \\
S9 & VE & SH & $18^{\circ} 58^{\prime} 40^{\prime \prime} \mathrm{S}, 47^{\circ} 38^{\prime} 42^{\prime \prime} \mathrm{W}$ & $170758,7 \mathrm{~m}^{2}$ \\
S10 & OP & $18^{\circ} 59^{\prime} 39^{\prime \prime} \mathrm{S}, 47^{\circ} 39^{\prime} 14^{\prime \prime} \mathrm{W}$ & $64062,0 \mathrm{~m}^{2}$ \\
S11 & AL & OP & $19^{\circ} 01^{\prime} 50^{\prime \prime} \mathrm{S}, 47^{\circ} 39^{\prime} 34^{\prime \prime} \mathrm{W}$ & $67012,2 \mathrm{~m}^{2}$ \\
S12 & AL & $18^{\circ} 59^{\prime} 48^{\prime \prime} \mathrm{S}, 47^{\circ} 35^{\prime} 46^{\prime \prime} \mathrm{W}$ & $26642,9 \mathrm{~m}^{2}$ \\
S13 & AL & OP & $19^{\circ} 00^{\prime} 37^{\prime \prime S}, 47^{\circ} 35^{\prime} 16^{\prime \prime} \mathrm{W}$ & $82613,6 \mathrm{~m}^{2}$ \\
\hline
\end{tabular}


vereda areas. At each hour, we walked a perimeter of 100 meters around the aquatic habitat that was repeated two times. We focused on adults only, since the majority of the larvae are still unknown (Garrison et al. 2006). The collection authorization process was issued by ICMBio, under the number 28398-1.

All specimens collected were preserved in acetone from 6 to 24 hours, according to their size, and later determined to genera level according to Garrison et al. (2006, 2010), and species level according to Lencioni $(2005,2006,2017)$ for Zygoptera. Additional Anisoptera identifications were made through specialized literature from each genus (e.g. Costa et al. 2002, von Ellenrieder 2009b). Species data were compared to the original species descriptions if needed. All specimens collected were deposited at the Laboratório de Ecologia - Evolução da Biodiversidade (LEEBIO), at Universidade Federal de Uberlândia, Uberlândia, Minas Gerais, Brazil.

\section{Statistical analysis}

Collection efforts and the number of sampled species were based on the richness percentage estimated by the mean of non-parametric estimator building the collector's curve by Jackknife1 to estimate the actual number of species. The Jackknife 1 and a rarefaction curve were calculated using the Software Estimates (Colwell 2009), with 1000 repetitions.

\section{Results}

In total, we sampled 680 specimens belonging to 6 families, 21 genera and 36 species (Table 2). Zygoptera were collected in greatest abundance $(\mathrm{n}=500)$, followed by Anisoptera $(\mathrm{n}=180)$. The family Coenagrionidae was the richest in species (15), followed by Libellulidae (13), Calopterygidae (3), Lestidae (2), Aeshnidae (2) and Gomphidae (1). The most abundant family was Coenagrionidae $(n=450)$ followed by Libellulidae $(n=175)$, Lestidae $(n=42)$, Calopterygidae $(n=10)$, Gomphidae $(n=4)$ and Aeshnidae $(n=2)$. Some of the sampled species are represented in Figure 2.

The most representative specie was Telebasis carmesina Calvert 1909 (Coenagrionidae), with 130 individuals, followed by Acanthagrion truncatum Selys, 1876 (Coenagrionidae), with 121, Oxyagrion microstigma Selys, 1876 (Coenagrionidae) with 90, Erythrodiplax castanea Burmeister, 1839 (Libellulidae) with 59 and Erythrodiplax latimaculata Ris, 1911 (Libellulidae) with 49 specimens. Those numbers represents $66 \%$ of the total collected specimens.

Distinctly, some species were less represented in abundance of specimens. The species Acanthagrion temporale Selys, 1876, Oxyagrion santosi Martins, 1967, Oxyagrion terminale Selys, 1876, Homeoura chelifera Selys, 1876, Tigriagrion sp. nov., Mnesarete pudica Hagen in Selys, 1853, Elasmothemis williamsoni Ris, 1919, Erythrodiplax ana Guillermo-Ferreira \& Vilela 2016, Micrathyria catenata Calvert, 1909, Micrathyria hesperis Ris, 1911, Orthemis discolor Burmeister, 1839, Anax amazili Burmeister 1839 and Remartinia luteipennis Burmeister 1839 , which represents $36 \%$ of the species richness, were represented by only one specimen each (singletons) at sampling. The species Cyanallagma nigrinuchale Selys, 1876, Erythrodiplax fusca Rambur, 1842 and Idiataphe longipes Hagen, 1861 were represented by two specimens (doubletons) each.
Although the samples were made at lentic systems, in three sampled points we saw tight channels with moving water close to the lentic habitats. On those points, we collected Hetaerina longipes Hagen \& Selys 1853, Hetaerina rosea Selys 1853, Mnesarete pudica, and Argia lilacina Selys, 1865, which are known to inhabit lotic environments, and a new species from the Tigriagrion genera.

The new species of Tigriagrion was collected in a vereda located in a shaded preserved Cerrado fragment, surrounded by high diversity of native plants, most trees and shrubs. The species are currently under description by taxonomists.

Some of the species found are widely spread in the national territory, as Acanthagrion gracile Rambur, 1842, A. truncatum, A. amazili, E. castanea, E. fusca, E. juliana Ris, 1911, E. latimaculata, H. rosea, Ischnura fluviatilis Selys, 1876, M. hesperis, Oligoclada abbreviata Rambur, 1842, and $O$. discolor. Others can be considered rare species, having more restricted distribution, as E. williamsoni, E. ana and $C$. nigrinuchale. Among the rare species, we found a new register for Minas Gerais state: Elasmothemis williamsoni (Libellulidae), that was previously collected in other Cerrado areas at Mato Grosso do Sul and Goiás States.

The rarefaction curve, which was based on the sampling events data, gave us a view of the sampling effectiveness of this study (Figure 3). The estimator showed that the richness found corresponds to $67 \%$ of the medium estimated richness by Jackknife 1 (Sest $=53.5 \pm 3.93)$.

\section{Discussion}

In general, the number of species in a single assemblage (pool) varies strongly in Brazilian Cerrado habitats, from as small as 26 and 31 species (Almeida et al. 2013, Vilela et al. 2016) to as numerous as 50-80, generally at sites with more sampled areas (Calvão et al. 2013, Carvalho et al. 2013, Dutra \& De Marco 2015, Ferreira-Peruquetti \& Fonseca-Gessner 2013) (Table 3). The number of species recorded in our study can be considered intermediary based on the small sampling effort, and the fact that we cover only half of the preserved area, indicating that the PANMC can present a rich pool of odonates, when compared to other places in Minas Gerais (Almeida et al. 2013, Souza et al. 2013). Additionally, there are many distinct Cerrado biotopes found around the aquatic habitats in the RLNMC, e.g, cerrado strictu sensu and campos de murundus, creating a gradient that could increase the diversity of odonates (Bedê et al. 2015).

Coenagrionidae has the greatest species number for the suborder Zygoptera in Brazil (Lencioni 2006). For instance, in our study, Acanthagrion lancea, A. truncatum, Oxyagrion microstigma and, Telebasis carmesina (Coenagrionidae), represented $50 \%$ of all collected specimens. These species were also widely found at Cerrado area in other studies (Ferreira-Peruquetti \& Fonseca-Gessner 2003, Calvão et al. 2014, Dutra \& De Marco 2015, Vilela et al. 2016, Rodrigues \& Roque 2017). Females of these Coenagrionidae species oviposits in aquatic plants from Eleocharis genera (Guillermo-Ferreira \& Del-Claro 2011, Vilela et al. 2016), which were commonly found at aquatic habitats in the study area. Probably, this may explain the high abundance of those species in our results. On the other hand, some other Zygoptera species, as Cyanallagma nigrinuchale, and Telebasis coccinea were collected in lower quantity. These species were restrict to shaded riparian areas 
Odonata from a Cerrado area in Minas Gerais

Table 2. Inventory list of Odonata species from Fazenda Nova Monte Carmelo, Minas Gerais (MG), Brazil, showing the localities, the characteristics of aquatic habitat and vegetation type where each species were collected, and the collection identity given to the species. AL: Artificial lake; VE: Vereda; OP: Open area; SH: Shaded area.

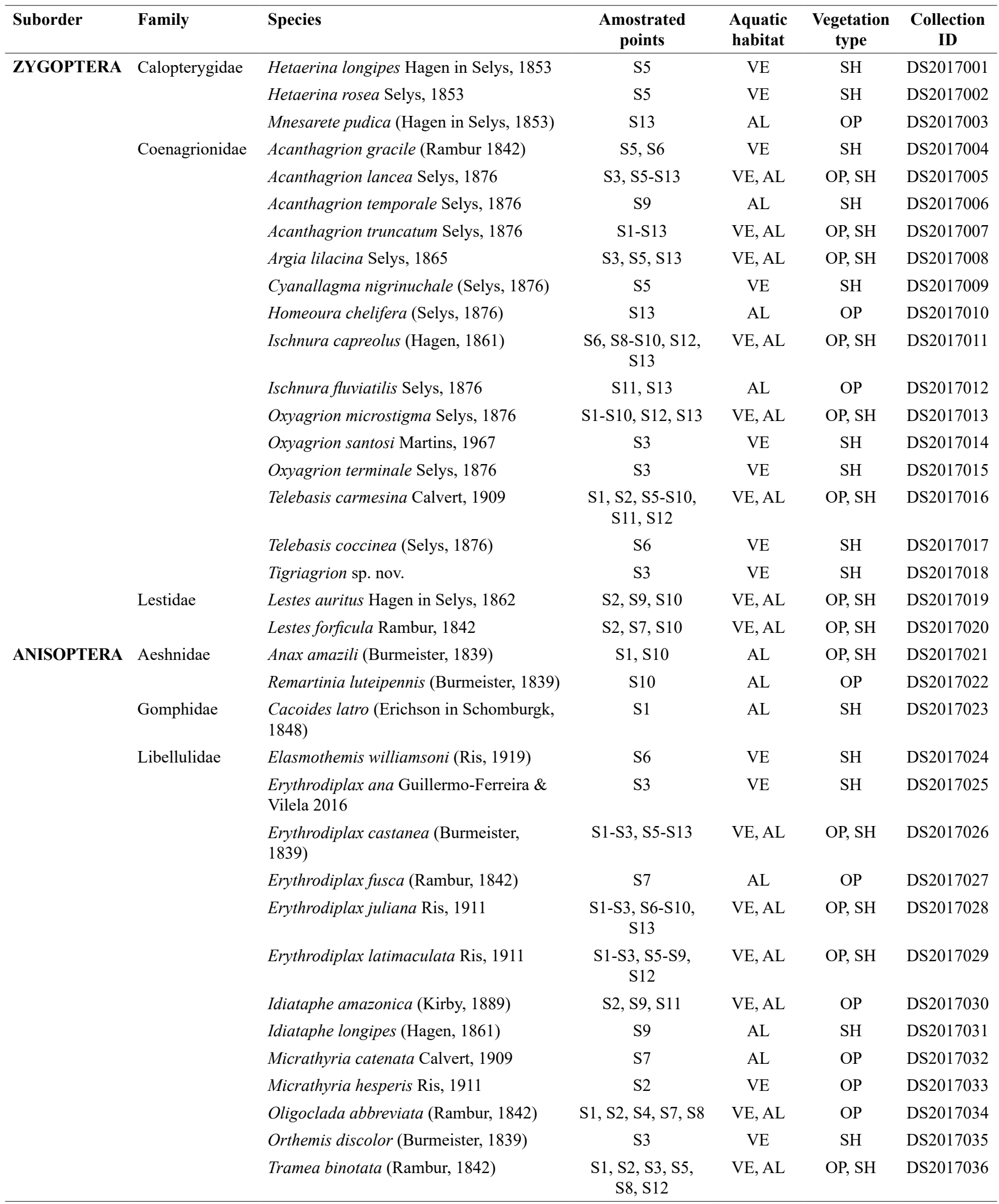


Borges, L.R. et al.
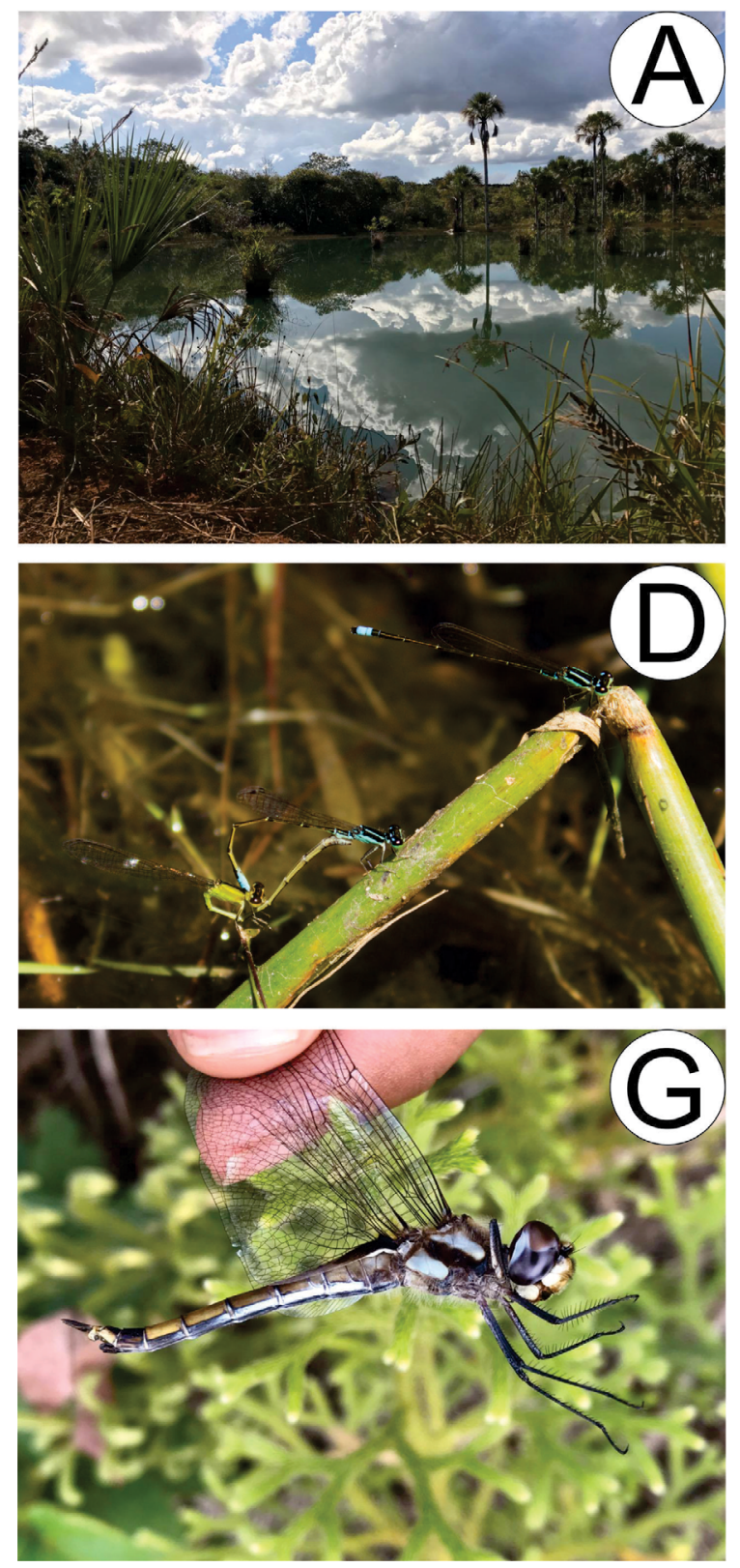

Figure 2. Two of 13 sampled sites in the Legal Reserve from Fazenda Nova Monte Carmelo, Brazil: a) a vereda surrounded by a preserved riparian zone; b) a vereda surrounded by a campo sujo fitofisionomy. Six of 36 collected species at Fazenda Nova Monte Carmelo, Minas Gerais (MG), Brazil: c) Cacoides latro (Gomphidae); d) Ischnura capreolus (Coenagrionidae); e) Idiataphe longipes (Libellulidae); f) Lestes forficula (Lestidae); g) Tramea binotata (female, Libellulidae); h) Mnesarete pudica (Calopterygidae).

and rarely are collected in surveys at Cerrado (Vilela et al. 2016, Dutra \& De Marco 2015).

The anisopteran species Erythrodiplax castanea, E. fusca, E. juliana, Idiataphe amazonica, Micrathyria hesperis, Oligoclada abbreviata, and Tramea binotata were found predominantly at open areas. These species has a wide geographic range and predominate in open vegetation areas (Machado et al. 1991, Costa et al. 2000, FerreiraPeruquetti \& Fonseca-Gessner 2003, Souza et al. 2013, Calvão et al. 2014, Bedê et al. 2015, Dutra \& De Marco 2015, Takiya et al. 2016, Rodrigues \& Roque 2017). The large occurrence of these species at open areas consists mostly due to the fact that many anisopteran species can be considered fliers: tend to have larger body size and are able to produce endogenous heat, controlling their inner temperature, flying most of the time and regulating their body temperature by controlling haemolymph (Corbet 1999, Corbet \& May 2008). Those characteristics can be attributed to the mosaic of open areas, that favors the occupation by the fast and agile flying dragonflies (see Machado et al. 1991). Considering the conservation perspective, those species could be less important in contrast with species found at shaded areas, which are less abundant, and have restricted distribution. Therefore, species with restricted distribution could indicate priority conservation areas for preserving Odonata species.

The low quantity of Aeshnidae, and Gomphidae species found can be associated with the fact that they are strong flyers, and species within some genera, as Gynachantha (Aeshnidae), presents phytotelmata and crepuscular habits (Bedê et al. 2000). Only one specimen of Anax 


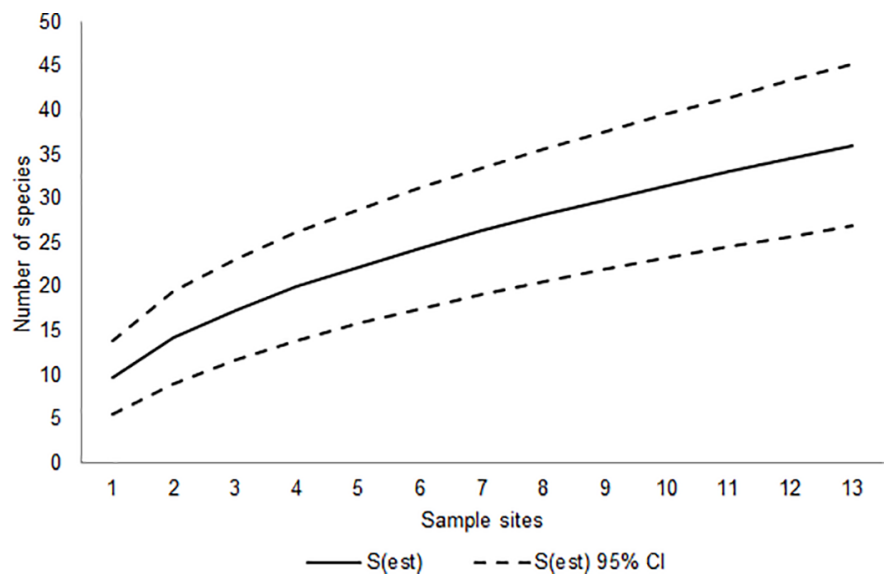

Figure 3. Rarefaction curve (Sest) and its Confidence Interval (Sest 95\% CI) of Odonata species collected at the Fazenda Nova Monte Carmelo, (MG), Brazil.

Table 3. Studies with adult Odonata at Cerrado biome, showing the number of collected species, the Federative Unit (FU), the season, and the number of sampled areas,

\begin{tabular}{lccc}
\hline Published studies & Richness & FU & Sampled areas \\
\hline Ferreira-Peruquetti \& Fonseca-Gessner 2003 & 85 & SP & MG \\
Almeida et al. 2013 & 26 & MT & 3 \\
Carvalho et al. 2013 & 53 & MT & 10 \\
Calvão et al. 2014 & 67 & GO & 9 \\
Dutra \& De Marco 2015 & 53 & MG & 58 \\
Vilela et al. 2016 & 31 & MG & 2 \\
Present study & $\mathbf{3 6}$ & $\mathbf{1 3}$ \\
\hline
\end{tabular}

amazili was collected, despite it has been seen in majority of the sampled areas and presents wide distribution in Brazil (Teixeira 1971, Dalzochio et al. 2012, Rodrigues \& Roque 2017). Almeida et al. (2013) had success at sampling Gomphidae species in Parque Nacional da Serra do Cipó, Minas Gerais state, by using malaise trap, and light sheet. Therefore, other methods can be tested for sampling species of these two families.

Only one Erythrodiplax ana specimen was collected in a shaded area within the Legal Reserve (Vereda). This specie was recently described, and found in another vereda within Triângulo Mineiro, located at Reserva Ecológica do Clube Caça e Pesca Itororó de Uberlândia, Minas Gerais state (Guillermo-Ferreira et al. 2016), about $44 \mathrm{~km}$ from the vereda where it was collected in Fazenda Nova Monte Carmelo. This specie was also collected at Parque Nacional da Chapada dos Guimarães (MT) (Guillermo-Ferreira et al. 2016), so far being restricted to Cerrado domain.

A male Elasmothemis williamsoni (Libellulidae) was collected in a shaded, well preserved riparian zone. As far we know, this specie was previously collected at Serra da Bodoquena in Mato Grosso do Sul state (Rodrigues \& Roque 2017), and in the southeastern region of Goiás state (Klein et al. 2018), being the both sites located within Cerrado biome.

The new finding of a Tigriagrion species reveals the importance that conservation measures has on this Cerrado area, that is under protection by the Brazilian Forest Code, and also adds important data about its distribution. It was found in a vereda at PANMC within a shaded riparian zone, where we found both lotic and lentic systems. Some other Tigriagrion species, as Tigriagrion aurantinigrum, are known to habit lotic systems, as streams (De Marco \& Vital 2008, Vilela et al. 2017).
We can see by our results that widespread and more restricted species, as the new finding Tigriagrion sp. nov., can inhabit aquatic habitats found in this Preserved Area. This results show the importance to continue preserving the aquatic habitats where those species occurs, and show that veredas can be an important fitofisionomy to inhabit rare Odonata species.

\section{Acknowledgements}

This study was partially supported by CNPq (Conselho Nacional de Desenvolvimento Científico e Tecnológico) through a Masters fellowship to the first author; Duratex through the permission given to access the Legal Reserve within Fazenda Nova Monte Carmelo, and financial support; PRONEX (Programa de Apoio a Núcleos de Excelência) through financial support; Universidade Federal de Uberlândia, through additional funding, and logistic support; ICMBio through the collection permit; and F.A.A. Lencioni, who confirmed and provided some information about the new species.

\section{Author Contributions}

Lucas Rodrigues Borges: Substantial contribution in the concept and design of the study. Contribution to data collection. Contribution to data analysis and interpretation. Contribution to manuscript preparation. Contribution to critical revision, adding intellectual content.

Marcela Silva Barbosa: Contribution to data collection. Contribution to data analysis and interpretation. 
Marco Antônio Alves Carneiro: Substantial contribution in the concept and design of the study. Contribution to data analysis and interpretation. Contribution to manuscript preparation. Contribution to critical revision, adding intellectual content.

Diogo Silva Vilela: Contribution to data analysis and interpretation. Contribution to manuscript preparation. Contribution to critical revision, adding intellectual content.

Jean Carlos Santos: Substantial contribution in the concept and design of the study. Contribution to data analysis and interpretation. Contribution to manuscript preparation. Contribution to critical revision, adding intellectual content.

\section{Conflicts of interest}

The authors declare that they have no conflict of interest related to the publication of this manuscript.

\section{References}

ALMEIDA, M.V.O., PINTO, A.P., CARVALHO, A.L. \& TAKIYA, D.M. 2013. When rare is just a matter of sampling: Unexpected dominance of clubtail dragonflies (Odonata, Gomphidae) throught differente collecting methods at Parque Nacional da Serra do Cipó, Minas Gerais State, Brazil. Rev. Bras. Entomol. 57(4): 417-423.

Alvarez, C.A., STAPE, J.L., SENTElHAS, P.C., DE MORAES, G., LEONARDO, J., SPAROVEK, G. 2013. Köppen's climate classification map for Brazil. Meteorol. Z. 22(6): 711-728.

ÁVILA, W.F., LENCIONI, F.A.A. \& CARNEIRO, M.A.A. 2017. Heteragrion cauei sp. nov., a new damselfly from Minas Gerais, Brazil (Odonata: Heteragrionidae). Odonatologica 46(3/4): 275-286.

BEDÊ, L.C., PIPER, W., PETERS, G. \& MACHADO, A.B.M. 2000. Phenology and oviposition behaviour of Gynacantha bifida Rambur in Brazil (Anisoptera: Aeshnidae). Odonatologica 29: 317-324.

BEDÊ, L.C., MACHADO, A.B.M., PIPER, W. \& SOUZA, M.M. 2015. Odonata of the Serra de São José - Brazil's first Wildlife Reserve aimed at the conservation of dragonflies. Notulae Odonatologicae 8(5): 117-155.

BINI, L.M., DINIZ-FILHO, J.A.F., RANGEL, T.F.L.V.B., BASTOS, R.P. \& PINTO, M.P. 2006. Challenging Wallacean and Linnean shortfalls: knowledge gradients and conservation planning in a biodiversity hotspot. Divers. Distrib. 12:475-82.

BRASIL. 2012. Lei Federal no 12.651, de 25 de maio de 2012. Novo Código Florestal Brasileiro. http://www.planalto.gov.br/ccivil_03/_ato20112014/2012/lei/112651.htm (last access on 01/05/2018).

CALVÃO, L.B., DE MARCO, P. \& BATISTA, J.D. 2014. Odonata (Insecta) from Nova Xavantina, Mato Grosso, Central Brazil: Information on species distribution and new records. Check List 10(2): 299-307.

CARVALHO, F.G., PINTO, N.S., OLIVEIRA-JUNIOR, J.M.B. \& JUEN, L. 2013. Effects of marginal vegetation removal on Odonata communities. Acta Limnol. Bras. 25: 10-18.

COLWELL, R.K. 2009. EstimateS: statistical estimates of species richness and shared species from samples, version $6.0 \mathrm{~b} 1$ : user's guide and application. Storrs: University of Connecticut. World Wide Web publication. http:// viceroy.eeb.uconn.edu/estimates/ (last access on 04/23/2018).

CORBET, P.S. 1999. Dragonflies: behavior and ecology of Odonata. Ithaca: Comstock Publ. Assoc. 829 p.

CORBET, P.S. \& MAY, M.L. 2008. Fliers and perchers among Odonata: dichotomy or multidimensional continuum? A provisional reappraisal. Intern. J. Odonatology 11: 155-71.

COSTA, J.M. \& OLDRINI, B.B. 2005. Diversidade e distribuição dos Odonata (Insecta) no Estado do Espírito Santo, Brasil. Publ. Av. Mus. Nac. 107:3-15.
COSTA, J.M., LOURENÇO, A.N. \& VIEIRA, L.P. 2002. Micrathyria pseudhypodidyma sp. n. (Odonata: Libellulidae), com Chave das Espécies do Gênero que Ocorrem no Estado do Rio de Janeiro. Neotrop. Entomol. 31(3): 377-389.

COSTA, J.M., MACHADO, A.B.M., LENCIONI, F.A.A. \& SANTOS, T.C. 2000. Diversidade e distribuição dos Odonata (Insecta) no Estado de São Paulo, Brasil: Parte I - Lista das espécies e registros bibliográficos. Publ. Av. Mus. Nac. 80: 1-27.

DALZOCHIO, M.S., STENERT, C. \& MALTCHIK, L. 2012. Odonata, Aeshnidae, Anax amazili (Burmeister, 1839): First record for southern Brazil. Check List 8(3): 551-553.

DE MARCO JR., P. \& VIANNA D.M. 2005. Distribuição do esforço de coleta de Odonata no Brasil - subsídios para escolha de áreas prioritárias para levantamentos faunísticos. Lundiana 6:13-26.

DE MARCO, P. \& VITAL, M.V.C. 2008. Ecology of Tigriagrion aurantinigrum Calvert in response to variations in environmental conditions (Zygoptera: Coenagrionidae). Odonatologica 37(1): 1-11.

DENNIS, R \& THOMAS, C. 2000. Bias in butterfly distribution maps: the influence of hot spots and recorder's home range. J. Insect Conserv. 4:73-77.

DIJKSTRA, K.B., MONAGHAN, M.T. \& PAULS, S.U. 2014. Freshwater Biodiversity and Aquatic Insect Diversification. Annu. Rev. Entomol. 59(1): 143-163.

DINIZ, J.A.F., DE MARCO, P. \& HAWKINS, B.A. 2010. Defying the curse of ignorance: perspectives in insect macroecology and conservation biogeography. Insect Conserv. Divers. 3: 172-179.

DUTRA, S., \& DE MARCO, P. 2015. Bionomic differences in odonates and their influence on the efficiency of indicator species of environmental quality. Ecol. Indic. 49: 132-142.

FERREIRA-PERUQUETTI, P. \& FONSECA-GESSNER, A.A. 2003. Comunidade de Odonata (Insecta) em áreas naturais de Cerrado e monocultura no nordeste do Estado de São Paulo, Brasil: relação entre o uso do solo e riqueza faunística. Rev. Bras. Zool. 20(2): 219-224.

GARRISON, R.W., VON ELLENRIEDER, N. \& LOUTON, J.A. 2006. Dragonfly genera of the new world: an illustrated and annotated key to the Anisoptera. The John Hopkins University Press, Baltimore, USA, 368 p.

GARRISON, R.W., VON ELLENRIEDER, N. \& LOUTON, J.A. 2010. Damselfly genera of the new world: an illustrated and annotated key to the Zygoptera. The John Hopkins University Press Baltimore, USA, 490 p.

GOTTSBERGER, G.; SILBERBAUER-GOTTSBERGER, I. 2006. I. Life in the Cerrado, a South American tropical seasonal ecosystem. Reta Verlag, Ulm, Germany, $280 \mathrm{p}$.

GUILLERMO-FERREIRA, R. \& DEL-CLARO, K. 2011. Oviposition site selection in Oxyagrion microstigma Selys, 1876 (Odonata: Coenagrionidae) is related to aquatic vegetation structure. Intern. J. Odonatology 14: 275-279.

GUILLERMO-FERREIRA, R., VILELA, D.S., DEL CLARO, K. \& BISPO, P.C. 2016. Erythrodiplax ana sp. nov. (Odonata: Libellulidae) from Brazilian palm swamps. Zootaxa 4158(2): 292-300.

HORTAL, J., LOBO, J.M. \& JIMENEZ-VALVERDE, A. 2007. Limitations of biodiversity databases: case study on seed-plant diversity in Tenerife, Canary Islands. Conserv. Biol. 21:853-63.

KALKMAN, V.J., CLAUSNITZER, V., DIJKSTA, K.D.B., PAULSON, R. \& VAN TOL, J. 2008. Global diversity of dragonflies (Odonata) in freshwater. Hydrobiologia 595: 351-363.

KLEIN, C.E., PINTO, N.S., SPIGOLONI, Z.A.V., BERGAMINI, F.M., DE MELO, F.R., DE MARCO, P. \& JUEN, L. 2018. The influence of small hydroelectric power plants on the richness and composition of Odonata species in the Brazilian Savanna. Int. J. Odonatol. 21: 33-44.

LENCIONI, F.A.A. 2005. The Damselflies of Brazil: An Illustrated Identification Guide 1 - The Noncoenagrionidae families. All Print Editora, São Paulo, Brazil, $324 \mathrm{p}$.

LENCIONI, F.A.A. 2006. The Damselflies of Brazil: An Illustrated Identification Guide 2 - Coenagrionidae. All Print Editora, São Paulo, Brazil, 419 p.

LENCIONI, F.A.A. 2017. Damselflies of Brazil - an illustrated identification guide - Southeast region. E-book, $559 \mathrm{p}$. 
MACHADO, A.B.M. 1998. Insetos. In: Machado, A. B. M. et al. eds. Livro Vermelho das Espécies Ameaçadas de Extinção da Fauna de Minas Gerais. Belo Horizonte: Fundação Biodiversitas, 605 p.

MACHADO, A.B.M., MESQUITA, H.G. \& MACHADO, P.A.R. 1991 Contribuição ao conhecimento dos odonatos da Estação Ecológica de Maracá. Acta Amaz. 21: 159-173.

MEYER, C., KREFT, H., GURALNICK, R. \& JETZ, W. 2015. Global priorities for an effective information basis of biodiversity distributions. Nat. Commun. 6: 82221

MIGUEL, T.B., CALVÃO, L.B., VITAL, M.V.C. \& JUEN, L. 2017. A scientometric study of the order Odonata with special attention to Brazil. Int. J. Odonatol. 20: 27-42.

MYERS, N., MITTERMEIER, R.A., MITTERMEIER, C.G., FONSECA, G.A.B. \& KENT, J. 2000. Biodiversity hotspots for conservation priorities. Nature (403): 853-858.

MONTEIRO-JUNIOR, C.S., JUEN, L. \& HAMADA, H. 2014. Effects of urbanization on stream habitats and associated adult dragonfly and damselfly communities in central Brazilian Amazonia. Landsc. Urban Plan. 127: 28-40.

PETERSON, A.T, SOBERON, J., PEARSON, R.G., ANDERSON, R.P., MARTÍNEZ-MEYER, E. 2011. Ecological Niches and Geographic Distributions. Princeton University Press, Princeton, NJ.

PINTO, A.P 2018. Odonata in Catálogo Taxonômico da Fauna do Brasil. PNUD. http://fauna.jbrj.gov.br/fauna/faunadobrasil/171 (last access on 05/29/2018).

RENNER, S., PÉRICO, E., SAHLÉN, G., SANTOS, D.M. \& CONSATTI, G. 2015. Dragonflies (Odonata) from the Taquari River valley region, Rio Grande do Sul, Brazil. Check list 11(5): 1740-1746.

RENNER, S., PÉRICO, E., ELY, G. J. \& SAHLÉN, G. 2017. Preliminary dragonfly (Odonata) species list from the Pampa biome in Rio Grande do Sul, Brazil, with ecological notes for 19 new records for the State. Biota Neotrop. 17(4): http://dx.doi.org/10.1590/1676-0611-BN-2017-0374 (last access on $09 / 22 / 2018$ ).

RODRIGUES, M.E. \& ROQUE, F.O. 2017. Checklist de Odonata do Estado de Mato Grosso do Sul, Brasil. Iheringia Sér. Zool. 117: 107-111.

SILVA, L.L. 2000. O papel do Estado no processo de ocupação das áreas de Cerrado entre as décadas de 60 e 80. Caminhos de Geografia 1(2): 24-36.
SOARES, D.M., NASCIMENTO, A.R.T., SILVA, L.C. \& DE-PINHO-JÚNIOR, G.V. 2015. Natural Regeneration and Biological Invasion by Pinus caribaea Morelet in Two Vereda Sites: Woody Vegetation Response. Am. J. Plant Sci. 6(17): 2708-2717.

SOUZA, M.M., PIRES, E.P., BRUNISMANN, A.G., MILANI, L.R. \& PINTO, A.P. 2017. Dragonflies and damselflies (Odonata) from the wetland of the Rio Pandeiros, northern region of Minas Gerais State, Brazil, with a description of the male of Archaeogomphus vanbrinki Machado (Anisoptera: Gomphidae) Int J Odonatol 20(1):13-26.

SOUZA, M.M., SOUZA, B., PEREIRA, M.C.S.A. \& MACHADO, A.B.M 2013. List of Odonates from Mata do Baú, Barroso, Minas Gerais, Brazil. Check List 9(6):1367-1370.

TAKIYA, D., SANTOS, A., PINTO, Â., HENRIQUES-OLIVEIRA, A., CARVALHO, A., SAMPAIO, B., CLARKSON, B., MOREIRA, F., AVELINO-CAPISTRANO, F., GONÇALVES, I., CORDEIRO, I., CÂMARA, J., BARBOSA, J., DE SOUZA, W. \& RAFAEL, J. 2016. Aquatic Insects from the Caatinga: checklists and diversity assessments of Ubajara (Ceará State) and Sete Cidades (Piauí State) National Parks, Northeastern Brazil. Biodivers. Data J. 195 p.

TEIXEIRA, M.C. 1971. Contribuição para o conhecimento da fauna odonatológica do Rio Grande do Sul. Arquivos do Museu Nacional 54: $17-24$.

VILELA, D.S., GUILLERMO-FERREIRA, R. \& DEL-CLARO, K. 2016. The odonata community of a Brazilian vereda: Seasonal patterns, species diversity and rarity in a palm swamp environment. Biosci. J. 32: 486-495.

VILELA, D.S., GUILLERMO-FERREIRA, R. \& DEL-CLARO, K. 2018. Argia angelae (Odonata: Zygoptera: Coenagrionidae) sp. nov. from Chapada dos Guimarães, Mato Grosso, Brazil. Zootaxa. 4415: 549-560.

VILELA, D.S., TOSTA, T.A., RODRIGUES, R.R., DEL-CLARO, K. \& GUILLERMO-FERREIRA, R. 2017. Colours of war: visual signals may influence the outcome of territorial contests in the tiger damselfly, Tigriagrion aurantinigrum. Biol. J Linnean Soc. 121: 786-795.

VON ELLENRIEDER, N. 2009 (a) . Databasing dragonflies: state of knowledge in the Neotropical region. Agrion 13: 58-72.

VON ELLENRIEDER, N. 2009 (b). Five new species of Orthemis from South America (Odonata: Libellulidae). Int. J. of Odonatol. 12(2): 347-381.

WHITTAKER, R.J., ARAUJO, M.B., PAUL, J., LADLE, R.J., WATSON, J.E.M. \& WILLIS, K.J. 2005. Conservation Biogeography: assessment and prospect. Divers. Distributions 11: 3-23. 
Borges, L.R. et al.

\section{Erratum}

In the article "Dragonflies and damselflies (Insecta: Odonata) from a Cerrado area at Triângulo Mineiro, Minas Gerais, Brazil" with the DOI code number http://dx.doi.org/10.1590/1676-0611-bn-2018-0609, published at Biota Neotropica 19(1):e20180609:

Where it was written:

Tramea binotata (Rambur, 1842)

Should read:

Tramea calverti Muttkowski, 1910

In page 4, where it was written:

In general, the number of species in a single assemblage (pool) varies strongly in Brazilian Cerrado habitats, from as small as 26 and 31 species (Almeida et al. 2013, Vilela et al. 2016) to as numerous as 50-80, generally at sites with more sampled areas (Calvão et al. 2013, Carvalho et al. 2013, Dutra \& De Marco 2015, Ferreira-Peruquetti \& Fonseca-Gessner 2013) (Table 3). The number of species recorded in our study can be considered intermediary based on the small sampling effort, and the fact that we cover only half of the preserved area, indicating that the PANMC can present a rich pool of odonates, when compared to other places in Minas Gerais (Almeida et al. 2013, Souza et al. 2013). Additionally, there are many distinct Cerrado biotopes found around the aquatic habitats in the RLNMC, e.g., cerrado strictu sensu and campos de murundus, creating a gradient that could increase the diversity of odonates (Bedê et al. 2015).

Should read:

Overall, the richness in an odonate community has a great disparity in Brazilian Cerrado habitats. In some areas, species richness is low, between 26 and 31 species (Almeida et al. 2013, Vilela et al. 2016). In other areas, the richness of species is relatively high, between 50 and 80 species, probably due to the fact that these areas present more sampling points, which increases the species richness (Calvão et al. 2013, Carvalho et al. 2013, Dutra \& De Marco 2015, Ferreira-Peruquetti \& Fonseca-Gessner 2013) (Table 3). The richness recorded in our study fits better on an intermediary level taking in account the small sampling effort, and the fact that we cover only half of the preserved area. These results indicate that the PANMC has the potential to hold a rich pool of odonates, in comparison to other places in Minas Gerais (Almeida et al. 2013, Souza et al. 2013). Moreover, around the aquatic habitats in the LRNMC, there are other different Cerrado phytophysiognomies, such as, cerrado strictu sensu and campos de murundus. These habitats can build a slope of environmental heterogeneity, which can boost the odonate diversity (Bedê et al. 2015, Souza et al. 2017).

In page 9, where it was written:

SOARES, D.M., NASCIMENTO, A.R.T., SILVA, L.C. \& DE-PINHO-JÚNIOR, G.V. 2015. Natural Regeneration and Biological Invasion by Pinus caribaea Morelet in Two Vereda Sites: Woody Vegetation Response. Am. J. Plant Sci. 6(17): 2708-2717.

SOUZA, M.M., SOUZA, B., PEREIRA, M.C.S.A. \& MACHADO, A.B.M. 2013. List of Odonates from Mata do Baú, Barroso, Minas Gerais, Brazil. Check List 9(6):1367-1370.

Should read:

SOARES, D.M., NASCIMENTO, A.R.T., SILVA, L.C. \& DE-PINHO-JÚNIOR, G.V. 2015. Natural Regeneration and Biological Invasion by Pinus caribaea Morelet in Two Vereda Sites: Woody Vegetation Response. Am. J. Plant Sci. 6(17): 2708-2717.

SOUZA, M.M., PIRES, E.P., BRUNISMANN, A.G., MILANI, L.R. \& PINTO, A.P. 2017. Dragonflies and damselflies (Odonata) from the wetland of the Rio Pandeiros, northern region of Minas Gerais State, Brazil, with a description of the male of Archaeogomphus vanbrinki Machado (Anisoptera: Gomphidae) Int J Odonatol 20(1):13-26.

SOUZA, M.M., SOUZA, B., PEREIRA, M.C.S.A. \& MACHADO, A.B.M. 2013. List of Odonates from Mata do Baú, Barroso, Minas Gerais, Brazil. Check List 9(6):1367-1370. 